\title{
The Effect of Management
} Morality on Accounting Fraud with Internal Control as A Moderating Variable (Study in Pemalang Regentcy)

Pratomo Cahyo Kurniawan and Fika Azmi

Program Studi Akuntansi, STIE Bank BPD Jateng

pratomokurniawan8@gmail.com

\section{Keywords:}

management morality, fraud, internal control.

\section{ABSTRACT}

This study aims to examine the effect of management morality on the tendency of accounting fraud with internal control as a moderating variable. The research was conducted at the District Office of Pemalang. A common problem in this research is the occurrence of corruption cases that occurred with the amount of loss and the large number of personnel involved in the corruption case. The sampling technique used is total sampling by using all members of the population as a sample of 70 samples. Data collection techniques using questionnaires distributed to the finance and accounting department at the District Office Pemalang. The analysis technique used is multiple linear regression analysis. The results of the analysis show that management morality has a negative effect on the tendency of accounting fraud. Interaction test results show that there is a significant positive influence of internal control in the relationship between management morality and the tendency of accounting fraud, so that internal control is a moderating variable. 
The government system changes from a pattern of centralization to decentralization. This is the impact of the enactment of the goverment regulation no. 32 of 2004, concerning regional government. Authority is widely given to regional governments to manage and utilize all of their potential, except those which are still the authority of the central government, such as religious affairs, defense and security issues, foreign political affairs, judicial, fiscal and monetary affairs.

Tuanakotta (2010) argues that fraud is an act of organizational personnel both from outside or inside that harms others by breaking the law to gain group and personal benefits. Frauds that occur are inseparable from pressure, opportunity, and rationalization. The concept is commonly referred to as the fraud triangle concept.

The Fraud Triangle theory proposed by Cressey (1953) states that there are three factors that can cause corruption, including opportunity, pressure, and rationalization. Corruption is one of the accounting frauds that often occurs in the government sector. Corruption is a fraud that is still common in Indonesia. The government through the Corruption Eradication Commission (KPK) continues to aggressively fight corruption that continues to occur in Indonesia. The following are data from the KPK as of December 31, 2017.

Table 1. Types of Corruption

\begin{tabular}{|llccc}
\hline No & $\begin{array}{c}\text { Types of } \\
\text { Corruption }\end{array}$ & $\begin{array}{c}\mathbf{2 0 0 4} \\
\text { to } \\
\mathbf{2 0 1 0}\end{array}$ & $\begin{array}{c}\mathbf{2 0 1 1} \\
\text { to } \\
\mathbf{2 0 1 7}\end{array}$ & $\begin{array}{c}\text { Number of } \\
\text { Cases }\end{array}$ \\
\hline 1 & $\begin{array}{l}\text { Licensing } \\
2\end{array}$ & 10 & 9 & 19 \\
& $\begin{array}{l}\text { Procurement } \\
\text { of Goods \& }\end{array}$ & 86 & 62 & 148 \\
& Services & & & \\
3 & Bribery & 57 & 205 & 262 \\
4 & Illegal Levies & 12 & 9 & 21 \\
5 & Budget Misuse & 31 & 13 & 44 \\
6 & $\begin{array}{l}\text { Money } \\
\text { Laundering }\end{array}$ & 0 & 15 & 15 \\
7 & $\begin{array}{l}\text { Blocking } \\
\text { Process at KPK }\end{array}$ & & 5 & 5 \\
\hline Source: Corruption Eradication Commission, 2017
\end{tabular}

The Corruption Eradication Commission (KPK) also revealed corruption cases that occurred in the period of $2004-2016$ where the most cases of corruption were in the government sector.
Table 2. List of Institutions Trapped in

Corruption Cases (2004-2017)

\begin{tabular}{clc}
\hline No & \multicolumn{1}{c}{ Name of Agency } & Number of Cases \\
\hline 1 & Ministries and & 225 \\
& Institutions & \\
2 & Regency and City & 109 \\
& Government & \\
3 & Provincial government & 82 \\
4 & DPR and DPRD & 46 \\
5 & BUMN and BUMD & 32 \\
6 & Commission & 20 \\
\hline & Total & 514 \\
\hline
\end{tabular}

Source: Corruption Eradication Commission, 2017

Internal Control System according to Government Regulation no. 60 of 2008 is a comprehensive system of actions and activities of leaders and all employees on an ongoing basis to provide confidence in an organization to achieve efficient and effective organizational goals, reliable financial reporting, security of state assets, and compliance with regulations.

One part of the Fraud Triangle Theory relating to the Internal Control System is opportunity. Opportunities are caused by the weakness of a system that is used to commit corruption. Employees who have the power and ability will take advantage of these weaknesses to commit fraud (Pristiyanti, 2012). Opportunities can be characterized by poor supervision of internal control (Wilopo, 2006), low adherence to internal control (Thoyyibatun et al. 2009), and opportunities in each position to commit fraud.

One of the Fraud's tendencies comes from the individual itself, one of which is morality. Moral is a term of positive action that is usually done by fellow humans (Ariani, 2014). Ramamoorti (2008) said that the root cause of fraud is from behavioral factors. Actors of fraud can come from internal (individuals) or external (companies). The process of transferring development roles, from moral reasoning to developing into a comprehensive structure, is more different and there are balancing factors that can compare with the previous structure (Kohlberg, 1995).

Pressure is a fraud that comes from the pressure of desire and motivation of each individual. The pressure can come from personal employees and from the organization. Pressure can also be in the form of financial or non-financial pressures (Pristiyanti, 2012). Rationalization is 
fraud that arises from behavior as a result of the commitment and personal moral discrepancies of employees (Rachmawati, 2014). Starting from this rationalization, there can be abuse of authority / conflicts of interest, bribery, illegal gratuities, tender games, and economic extortion that lead to criminal acts of corruption (Sayyid, 2014).

Table 3. Corruption Cases in Central Java in 2010 - 2017

\begin{tabular}{|c|c|c|c|c|}
\hline No & $\begin{array}{c}\text { City/ } \\
\text { Regency }\end{array}$ & $\begin{array}{c}\text { Num } \\
\text { of } \\
\text { Cases }\end{array}$ & $\begin{array}{l}\text { Num of } \\
\text { suspects }\end{array}$ & $\begin{array}{c}\text { Total } \\
\text { State } \\
\text { Losses }\end{array}$ \\
\hline 1 & Kota Tegal & 2 & 3 & $\mathrm{Rp} 23 \mathrm{~b}$ \\
\hline 2 & Kota Salatiga & 3 & 5 & $\mathrm{Rp} 12.4 \mathrm{~b}$ \\
\hline 3 & Kab. Karanganyar & 2 & 8 & $\mathrm{Rp} 11.4 \mathrm{~b}$ \\
\hline 4 & Kota Semarang & 3 & 6 & $\mathrm{Rp} 7.3 \mathrm{~b}$ \\
\hline 5 & Kab. Sragen & 2 & 5 & $\mathrm{Rp} \quad 6.7 \mathrm{~b}$ \\
\hline 6 & Kab. Sukoharjo & 2 & 3 & $\mathrm{Rp} \quad 4.4 \mathrm{~b}$ \\
\hline 7 & Kab. Pemalang & 3 & 24 & $\mathrm{Rp} \quad 4.2 \mathrm{~b}$ \\
\hline 8 & Kab. Cilacap & 2 & 2 & $\mathrm{Rp} \quad 3.7 \mathrm{~b}$ \\
\hline 9 & Kab. Jepara & 2 & 6 & $\mathrm{Rp} 3.1 \mathrm{~b}$ \\
\hline 10 & Kab. Rembang & 3 & 8 & $\mathrm{Rp} \quad 2.8 \mathrm{~b}$ \\
\hline 11 & Kab. Kendal & 5 & 7 & $\mathrm{Rp} \quad 2.5 \mathrm{~b}$ \\
\hline 12 & Kab. Boyolali & 3 & 9 & $\mathrm{Rp} \quad 1.9 \mathrm{~b}$ \\
\hline 13 & Kab. Blora & 1 & 1 & $\mathrm{Rp} \quad 1.7 \mathrm{~b}$ \\
\hline 14 & Kab. Magelang & 2 & 3 & $\mathrm{Rp} \quad 1.7 \mathrm{~b}$ \\
\hline 15 & Kab. Wonosobo & 1 & 1 & $\operatorname{Rp} 1.5 b$ \\
\hline 16 & Kab. Kebumen & 2 & 4 & $\mathrm{Rp} 1.3 \mathrm{~b}$ \\
\hline 17 & Kab. Semarang & 2 & 2 & $\mathrm{Rp} \quad 1.1 \mathrm{~b}$ \\
\hline 18 & $\begin{array}{l}\text { Kab. } \\
\text { Banjarnegara }\end{array}$ & 2 & 2 & $\mathrm{Rp} \quad 1 \quad \mathrm{~b}$ \\
\hline 19 & Kab. Kudus & 2 & 2 & $\mathrm{Rp} 843 \mathrm{~m}$ \\
\hline 20 & Kab. Banyumas & 4 & 7 & $\mathrm{Rp} 815 \mathrm{~m}$ \\
\hline 21 & Kab. Wonogiri & 4 & 4 & $\mathrm{Rp} 806 \mathrm{~m}$ \\
\hline 22 & Kota Magelang & 1 & 1 & $\mathrm{Rp} 601 \mathrm{~m}$ \\
\hline 23 & Kab. Pekalongan & 2 & 2 & $\mathrm{Rp} 562 \mathrm{~m}$ \\
\hline 24 & Kota Solo & 2 & 2 & $\mathrm{Rp} 356 \mathrm{~m}$ \\
\hline 25 & Kab. Klaten & 3 & 3 & $\mathrm{Rp} 345 \mathrm{~m}$ \\
\hline 26 & Kota Pekalongan & 3 & 3 & $\mathrm{Rp} 330 \mathrm{~m}$ \\
\hline 27 & Kab. Pati & 1 & 2 & $\mathrm{Rp} 261 \mathrm{~m}$ \\
\hline 28 & Kab. Batang & 1 & 1 & $\mathrm{Rp} 200 \mathrm{~m}$ \\
\hline 29 & Kab. Brebes & 1 & 1 & $\mathrm{Rp} 150 \mathrm{~m}$ \\
\hline 30 & Kab. Demak & 1 & 1 & $\mathrm{Rp} 90 \mathrm{~m}$ \\
\hline 31 & Kab. Grobogan & 1 & 1 & $\mathrm{Rp} 60 \mathrm{~m}$ \\
\hline 32 & Kab. Purworejo & - & - & - \\
\hline 33 & Kab. Temanggung & - & - & - \\
\hline 34 & Kab. Tegal & - & - & - \\
\hline 35 & Kab. Purbalingga & - & - & - \\
\hline
\end{tabular}

Source: Infokorupsi.com, KP2KKN, Directory of MA Verdict

Based on the data in Table 3, Pemalang district ranks 7th in Central Java, which suffers from a substantial state loss of Rp. 4.2 billions. The number of suspects involved in corruption cases amounted to 24 suspects and the highest number among regencies and cities in Central Java Province.

The second reason is from the LKPD (Regional Government Financial Statements) data of Pemalang Regency to obtain WDP (Fair with Exceptions) opinions seven times in a row from 2010 to 2017 from the Central Java BPK. According to the BPK, which led to the opinion of the WDP, among others: The distribution of investment in some offices is still not maximal, it is unclear whether non-permanent investments to regional enterprises of various businesses (PDAU) are not supported by adequate data regarding nonpermanent investments.

Based on these data, it can be said that the accounting system and financial reporting of local governments in the implementation process are not significantly influential to anticipate all fraud and irregularities. This is increasingly interesting to examine regarding the effect of management morality and internal control as moderating variables on accounting fraud tendencies.

\section{LITERATURE REVIEW AND HYPOTHESIS FORMULATION}

\section{Management Morality and Accounting Fraud}

The Fraud triangle explains fraud can occur when there are situations with high pressure, there are opportunities and supported by individuals with low integrity. Albrecht (2004) states that the desire factor to seek personal gain is a motivation for someone to commit accounting fraud. Fraud can be caused by the behavior of rationalization (Amin, 2009). Moral is related to the good side and the bad side of humans, so that the good side is seen as a field of life (Magnis, 2004). Morality is an attitude of true morality (Magnis, 2004). Morality also includes outward actions that are reflected in the attitude of one's heart. Morality can be said as actions and attitudes that are selfless and morally have values (Magnis, 2004). Fraud that occurs in financial statements can be triggered by behavior or morals of a person, that is by changing behavior and trying to cover up by manipulating financial statements in order to abuse assets or cash (Amin, 2009).

Wilopo (2006) in his study explained that management morality towards accounting fraud has a significant negative effect. If management morality is higher, accounting fraud will be lower. 
Management's attention will be broader and exceed the interests of the company or individual. The research results of Sumiati (2010) also explain that morality has a significant negative effect on the level of fraudulent financial statements. If management moral is low, it tends to lead to fraudulent behavior and results in the company losing money, the actor will also take action to manipulate financial report data to trick fraudulent actions, so the research hypothesis is:

H1: Management morality has a negative effect on accounting fraud.

\section{Internal Control and Accounting Fraud}

The Fraud Triangle theory explains that weak internal control will affect the amount of opportunity to commit accounting fraud. Weak internal control can be used as an opportunity to commit fraud. Effective internal control can protect from theft, embezzlement, misuse of assets in inappropriate locations. In addition, internal control also provides a reasonable guarantee of accurate business information for the success of the company (Giarini, 2015).

The results of the Giarini study (2015) show that internal control affects accounting fraud. Wilopo's research (2006) also shows that internal control has a negative effect on accounting fraud. Fauwzi and Yuyetta (2011) in their research also showed the same results, namely internal control had a negative effect on accounting fraud, so the research hypothesis was:

H2: Internal Control has a negative effect on accounting fraud

\section{Management Morality, Internal Control, Accounting Fraud}

Based on the theory of the Fraud Triangle, the opportunity to commit accounting fraud can be influenced by the conditions of the opportunity and the absence of opportunities to utilize weak internal controls. Accounting fraud can occur due to the size of the opportunity. Good internal control can close opportunities for accounting fraud (Fauwzi and Yuyetta, 2011).

Systems that are designed and supported with good internal control can prevent the occurrence of fraud either fraud committed by internal or external companies (Amrizal, 2004). The company's wealth will not be guaranteed if the internal control system is weak. This will also result in ineffective and inefficient operational activities of the company, information that is less reliable, and will even ignore management policies (Wilopo, 2006).

Thoyibatun's research, et al (2009) shows the results that internal control has a significant negative effect on accounting fraud, as well as the research by Fauwzi and Yuyetta (2011) showing the same results, which found significant negative effects of internal control over accounting fraud. Eliza (2015) in her research at the SKPD in Padang city showed that the results of the internal control system had a significant negative effect on accounting fraud. Individuals with a low moral level when committing fraud will depend on the presence or absence of internal control elements. Conversely, individuals with high moral levels will not influence the presence or absence of internal control elements when conducting accounting fraud (Prawira, et al 2014).

Accounting fraud will be influenced by the existence of interactionsbetweenindividualmorality and internal control (Puspasari and Suwardi, 2012). The interaction comes from changes in moral level and internal control conditions, where accounting fraud is caused by individual changes. Conditions without internal control elements will be used to meet the personal interests of individuals who have a low level of moral reasoning. This is in accordance with Kohlberg's moral level, that individuals with pre-conventional levels will commit fraud for their own sake. Whereas individuals with high levels of moral reasoning will not behave fraudulently which will harm others even though there is no element of internal control.

Puspasari and Suwardi's (2012) research shows the existence of interactions between individual moral levels and internal controls. Accounting fraud will not be carried out by individuals who have a high moral level, whether it is supported by the presence or absence of internal control elements. Accounting fraud that occurs in agencies can be reduced by effective internal controls (Fauwzi and Yuyetta, 2011). The compiled hypothesis is:

H3: Internal control moderates the effect of management morality on accounting fraud 


\section{Research model}

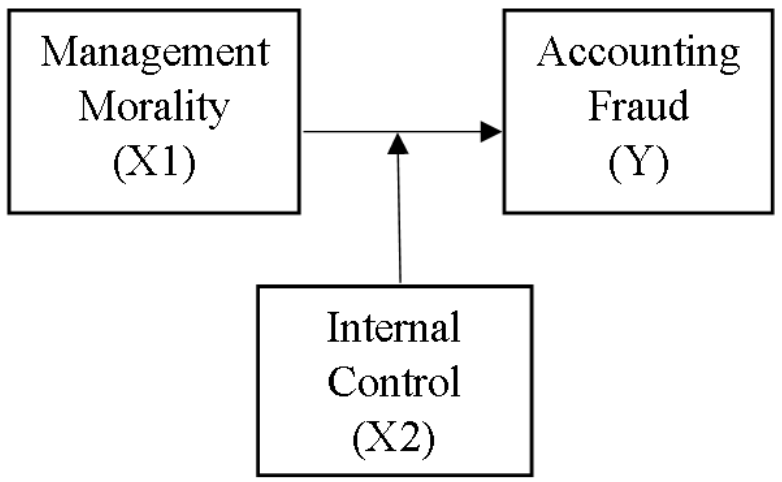

\section{RESEARCH METHODS}

\section{Research design}

This study uses primary data collected through the results of respondents' answers to questions given to participants directly in the field. Questionnaires were distributed to Civil Servants in the Finance and Accounting Department at Pemalang District Government. The tendency of accounting fraud to be used as the dependent variable, management morality as an independent variable, and internal control as a moderating variable.

\section{Population}

The population in this study were civil servants in the finance and accounting department in Pemalang District. The first reason for selecting the population, the finance and accounting department has a great opportunity to commit fraud because it is related to disbursement, use and budget reporting. The second reason is based on the results of the BPK audit of Pemalang Regency local government financial report (LKPD) which still shows that there is no significant influence from the application of the accounting system and the application of government financial reporting to prevent fraud or errors. Data on the number of Dinas population in Pemalang Regency are found in the following table;

Table 4

\begin{tabular}{clc}
\hline No & $\begin{array}{c}\text { Official in Pemalang } \\
\text { Regency }\end{array}$ & Population \\
\hline 1 & Youth and Sports & 7 \\
2 & Education Official & 7 \\
2 & Public Health Official & Agriculture and Forestry \\
3 & Official & 7 \\
\hline
\end{tabular}

\begin{tabular}{clc}
\hline No & \multicolumn{1}{c}{$\begin{array}{c}\text { Official in Pemalang } \\
\text { Regency }\end{array}$} & Population \\
\hline 4 & $\begin{array}{l}\text { Social, Labor and } \\
\text { Transmigration Official }\end{array}$ & 7 \\
5 & $\begin{array}{l}\text { Culture and Tourism } \\
\text { Official }\end{array}$ \\
6 & $\begin{array}{l}\text { Marine and Fisheries } \\
\text { Official }\end{array}$ & 7 \\
7 & $\begin{array}{l}\text { Public Works Official } \\
\text { Revenue, Regional }\end{array}$ & 7 \\
8 & $\begin{array}{l}\text { Financial and Asset } \\
\text { Management Official }\end{array}$ & 8 \\
9 & $\begin{array}{l}\text { Population and Civil } \\
\text { Registry Official }\end{array}$ \\
10 & $\begin{array}{l}\text { Cooperatives, Industry } \\
\text { and Trade Official }\end{array}$ & 7 \\
\hline & Total Population & 70 \\
\hline
\end{tabular}

\section{Analysis Techniques}

Data analysis techniques using Test Validity and Reliability, Classical Assumption Test, Multiple Linear Regression Test, $\mathrm{F}$ Test and $\mathrm{t}$ Test.

1. Test Validity and Reliability

a) Test Validity

Questionnaires were measured using validity tests to find out whether they were valid or not. The questions in a valid questionnaire can be revealed and can be measured. Validity test can be seen from the value of correlated items, it can be said to be valid with the criteria of $r$ count $>r$ table and is positive (Ghozali, 2011).

b) Reliability Test

Questionnaire answers were measured by reliability tests aim to find out the answers to a stable or consistent questionnaire. Instrument reliability was tested using the Cronbachs Alpha Coefficient. Reliable instruments have Alpha Coefficient criteria of more than 0.6 (Ghozali, 2011).

2. Multiple Linear Regression Models This study uses the interaction test or Moderated Regression Analysis (MRA), where the regression equation has an interaction between independent variables, used to measure the influence of the moderating variable (internal control) on the relationship between management morality as an independent variable and accounting fraud tendency as the dependent variable (Ghozali, 2011) 
3. F Test

Simultaneous influence of the independent variable on the dependent variable can be known by using the $\mathrm{F}$ test. The criteria is $\mathrm{Ha}$ is accepted if the Sig value is $<0.05$ or F count $>$ $\mathrm{F}$ table, whereas if the Ha value is $>0.05$ then $\mathrm{Ha}$ is rejected because there is no influence simultaneous between independent variables and dependent variables (Ghozali, 2011).

4. $\mathrm{t}$ Test

Partial influence of independent variables on the dependent variable can be known using the $t$ test. The criteria are if the Sig value is < 0.05 then $\mathrm{Ha}$ is accepted ( $\mathrm{t}$ count $>\mathrm{t}$ table), if the value of $t$ is calculated $<t$ table (Sig value $>$ 0.05) then Ha is rejected (Ghozali, 2011).

\section{RESULTS AND DISCUSSION}

\section{Normality test}

Table 5. One-Sample Kolmogorov - Smirnov Test

\begin{tabular}{lc}
\hline & $\begin{array}{c}\text { Unstandardized } \\
\text { Residual }\end{array}$ \\
\hline Kolmogorov-Smirnov Z & 0,874 \\
Asymp. Sig. (2-tailed) & 0,430 \\
\hline Source: Primary data that has been processed, 2017
\end{tabular}

The magnitude of the Kolmogorof-Smirnov value is 0.874 and the significance value is 0.430 which is not significant at 0.05 . This can be concluded that the residual data is normally distributed.

\section{Multicollinearity Test}

Table 6. Multicollinearity Test

\begin{tabular}{llc}
\hline \multirow{2}{*}{ Model } & \multicolumn{2}{c}{ Collinearity Statistics } \\
\cline { 2 - 3 } & Tolerance & \multicolumn{1}{c}{ VIF } \\
\hline Morality & 0,984 & 1,017 \\
ICS & 0,984 & 1,017 \\
\hline
\end{tabular}

Source: Primary data that has been processed, 2017

The results of the calculation of tolerance values indicate that there is no independent variable that has a tolerance value of less than 0.10 , which means there is no correlation between independent variables whose value is more than $95 \%$. The results of the calculation of the Variance Inflation Factor (VIF) value also show the same thing where there is not one independent variable that has a VIF value of more than 10. The conclusion is that there is no multicolonity between independent variables in the regression model.

\section{Heteroscedasticity Test}

Table 7. Glejser Test

\begin{tabular}{cc} 
Variable & Sig \\
\hline Morality & 0,464 \\
ICS & 0,463 \\
\hline
\end{tabular}

Source: Primary data that has been processed, 2017

The test results show a significance value of $>0.05$, it can be concluded that there is no heteroscedasticity in the regression model.

\section{F Test}

Table 8. F Test

\begin{tabular}{ccc} 
Model & F & Sig. \\
\hline Regression & 12,522 & 0,000 \\
\hline Source: Primary data that has been processed, 2017
\end{tabular}

ANOVA test or $\mathrm{F}$ test shows that the calculated F value is 12,522 with a probability of 0,000 . The resulting probability is less than 0.05 , so the regression model can be used to predict Accounting Fraud Trends or it can be said that Management Morality and Internal Control simultaneously influence the Accounting Fraud Trend.

\section{t Test}

Table 9. $t$ Test

\begin{tabular}{lccc}
\multicolumn{1}{c}{ Variable } & B & T & Sig \\
\hline Constants & 97,652 & 14,764 & 0,000 \\
Morality & $-0,671$ & $-3,398$ & 0,001 \\
ICS & $-0,172$ & $-3,311$ & 0,001 \\
\hline $\mathrm{R}^{2}$ & \multicolumn{3}{c}{$0,257(25,7 \%)$} \\
\hline
\end{tabular}

Source: Primary data that has been processed, 2017

\section{MRA Test}

Table 10. MRA Test

\begin{tabular}{lccc}
\multicolumn{1}{c}{ Variable } & B & T & Sig \\
\hline Constants & 203,429 & 5,606 &, 000 \\
Morality & $-6,322$ & $-3,295$ &, 002 \\
ICS & $-1,110$ & $-3,461$ &, 001 \\
Interaction & 0,050 & 2,959 &, 004 \\
\hline $\mathrm{R}^{2}$ & \multicolumn{3}{c}{$0,334(33,4 \%)$} \\
\hline
\end{tabular}

Source: Primary data that has been processed, 2017 


\section{Discussion}

1. Effect of Management Morality on Accounting Fraud

The results of the regression analysis in this study indicate that the first hypothesis (H1) is accepted and it can be concluded that management morality has a negative effect on accounting fraud. This can be seen from the independent variable management morality has a regression coefficient with a negative sign of 0.671 which means that the effect of management morality on accounting fraud is negative. Significance value of 0.001 which is smaller than the confidence level $(\alpha)$ of 0.05 . The results of this study are consistent with research conducted by Wilopo (2006), Fauwzi and Yuyetta (2011), Puspasari and Suwardi (2012), Aranta (2013), Ariani (2014), Prawira (2014), Eliza (2015) which states that management morality has a negative effect on accounting fraud.

The results of this study mean that the higher the management morality, the tendency to commit accounting fraud will decrease. Morality is an important factor that can influence a person's behavior and actions. Management morality in an institution has a great influence on accounting fraud that might occur in the agency (Fauwzi and Yuyetta, 2011).

\section{Effect of Internal Control on Accounting Fraud}

The results of the regression analysis conducted in this study show that the second hypothesis (H2) is accepted and it can be concluded that internal control has a negative effect on accounting fraud. These results support the research hypothesis. This can be seen from the independent variable internal control has a regression coefficient with a negative sign of 0.172 which means that the effect of management morality on accounting fraud is negative. Significance value of 0.001 which is smaller than the confidence level ( $\alpha$ ) of 0.05 .

The results of this study are consistent with the research conducted by Thoyyibatun (2009), Fauwzi and Yuyetta (2011), Ariani (2014), and Eliza (2015) which state that internal control has a negative effect on accounting fraud. The results of this study indicate that internal control can reduce accounting fraud that occurs in agencies. Effective internal control of agencies can minimize opportunities for individuals to cheat (Thoyyibatun, 2009).

\section{Effects of Management Morality, Internal Control and Accounting Fraud}

The interaction test results show a significance value of 0.04 which is smaller than the confidence level $(\alpha)$ of 0.05 . These results support the research hypothesis. This means that internal control strengthens the influence of management morality on accounting fraud. This result is consistent with research conducted by Wilopo (2006), Thoyyibatun (2009), Fauwzi and Yuyetta (2011), Puspasari and Suwardi (2012), Ariani (2014), Prawira (2014) and Eliza (2015).

\section{CONCLUSION}

The conclusions from the results of this study are as follows:

1. The first hypothesis which states that management morality has a negative influence on the tendency of accounting fraud to be accepted. These results indicate that high morality can reduce the occurrence of accounting fraudulent tendencies, and vice versa if low management morality will trigger the occurrence of accounting fraudulent tendencies in an agency or organization.

2. The second hypothesis which states that internal control has a negative influence on the tendency of accounting fraud to be accepted. These results indicate that internal control applied to agencies can reduce the tendency of accounting fraud and minimize the opportunity for individuals to commit fraud.

3. The third hypothesis states that internal control moderates the effect of management morality on the tendency of accounting fraud to be accepted. These results indicate that internal control strengthens the influence of management morality on accounting fraud tendencies. High management morality accompanied by the implementation of internal controls will minimize the chance of accounting fraud tendency in the agency. 
Albrecht, S. W. and C. Albrecht. 2004. "Fraud Examination and Prevention". Australia: Thomson, SouthWestern.

Amin Widjaja. 2009. "Kecurangan Laporan Keungan (Financial Statement Fraud)", Jakarta : PT. Indeks.

Amrizal, 2004, "Pencegahan dan Pendeteksian kecurangan oleh internal auditor". www.bpkp.go,id. Diakses pada 3 Maret 2016.

Aranta, Petra Zulia. 2013. "Pengaruh Moralitas Aparat dan Asimetri Informasi Terhadap Kecenderungan Kecurangan Akuntansi Pemerintah Kota Sawahlunto". FE UNP.

Ariani, Musmini, dan Herawati. 2014. "Analisis Pengaruh Moralitas Individu, Asimetri Informasi, dan Keefektifan Sistem Pengendalian Internal Terhadap Kecenderungan Kecurangan Akuntansi di PDAM Kab Bangli". Jurnal Akuntansi Universitas Pendidikan Ganesha. Volume 2.

Cressey, D. 1953. "Other People's Money: a Study in the Social Psychology of Embezzlement. Glencoe”. IL: Free Press.

Eliza, Yulina. 2015. "Pengaruh Moralitas Individu dan Pengendalian Internal terhadap Kecenderungan Kecurangan Akuntansi pada SKPD Kota Padang".STIE Perdagangan Padang. Jurnal Akuntansi volume 4 no 1 , halaman :86-100.

Fauwzi, Mohammad dan Etna N.A Yuyetta. 2011. "Analisis Pengaruh Keefektifan Pengendalian Internal, Persepsi Kesesuaian Kompensasi, Moralitas Manajemen terhadap Perilaku Tidak Etis dan Kecenderungan Kecurangan Akuntansi”. FE Undip.

Ghozali, I. 2011. "Aplikasi Analisis Multivariate Dengan Program IBM SPSS 19”. Edisi Keenam, Penerbit Universitas Diponegoro.

Giarini, Frisaha. 2015. "Pengaruh Efektifitas Pengendalian Internal, Kesesuaian Kompensasi, dan Asimetri Informasi terhadap Kecenderungan Kecurangan Akuntansi”. FEB UMS.

Infokorupsi.com. Diakses pada 3 Maret 2016.

Kejaksaan Republik Indonesia. www.kejaksaan.go.id. Diakses pada 3 Maret 2016.

Kohlberg, L. 1995. “Tahap-tahap Perkembangan Moral”, diterjemahkan oleh Drs. John de Santo dan Drs. Agus Cremers SVD, Penerbit Kanisius: Yogyakarta.

Komisi Pemberantasan Korupsi (KPK). "Penanganan Tindak Pidana Korupsi Berdasarkan Jenis Perkara”. www.kpk.go.id. Diakses pada 3 Maret 2016.

Magnis, Suseno Franz. 2004. Etika Jawa Sebuah Analisa Falsafi tentang Kebijaksanaan Hidup Jawa. PT Gramedia pustaka Utama: Jakarta

Mayangsari dan Wilopo. 2002. "Konservatisme Akuntansi, Value Relevance dan Discretionary Accruals: Implikasi Empiris Model Feltham-Olhson (1996)". Jurnal Riset Akuntansi Indonesia, vol. 5, no. 3 (September), Hal: 291-310.

Peraturan Pemerintah No.60 tahun 2008 tentang Sistem Pengendalian Internal Pemerintah (SPIP). www. bpkp.go.id. Diakses pada 3 Maret 2016.

Prawira, Herawati, dan Darmawan. 2014. "Pengaruh Moralitas Individu, Asimetri Informasi, dan Efektifitas Pengendalian Internal terhadap Kecenderungan Kecurangan Akuntansi pada BUMD Kab Buleleng”. Jurnal Akuntansi UPG, Vol 2 No 1.

Pristiyanti, Ika Ruly. 2012. "Persepsi Pegawai Instansi Pemerintah Mengenai Faktor-Faktor yang Mempengaruhi Fraud di Sektor Pemerintahan". Jurnal Akuntansi. Fakultas Ekonomi UNNES, Vol 1 No 1.

Puspasari, dan Suwardi. 2012. "Pengaruh Moralitas Individu dan Pengendalian Internal terhadap Kecenderungan Kecurangan Akuntansi: Studi Eksperimen pada Konteks Pemerintahan Daerah". Simposisum Nasional Akuntansi 15. 
Putusan Mahkamah Agung.go.id. Diakses pada 3 Maret 2016.

Rachmawati, Kurnia Kusuma. 2014. "Pengaruh Faktor - Faktor dalam Perspektif Fraud Triangle Terhadap Fraudulent Financial Reporting”. FE Undip.

Ramamoorti, S. 2008. "The Psychology and Sociology of Fraud: Integrating the Behavioral Sciences Component Into Fraud and Forensic Acounting Curricula”. Issues in Accounting Education vol. 23.

Sayyid, Annisa. 2014. “Pemeriksaan Fraud dalam Akuntansi Forensik dan Audit Investigatif”. IAIN Antasari Banjarmasin. Al-Banjari, 137-162.

Sumiati, Friskila Rini. 2010. "Pengaruh Ketaatan Akuntansi, Sistem Pengendalian Intern, Kesesuaian Kompensasi Dan Moralitas Terhadap Kecendrungan Kecurangan Akuntansi (Fraud) Pada Badan Usaha Milik Negara di Padang”. FE UNP.

Thoyyibatun. 2009. "Analysing The Influence of Internal Control Compliance And Compensation System Against Unethical Behavior And Accounting Fraud Tendency (Studies at State University in East Java). Palembang": Simposium Nasional Akuntansi XII.

Tuannakotta, Theoderus M. 2010. “Akuntansi Forensik dan Audit Investigatif”. LP-FEUI: Jakarta.

Wilopo. 2006. “Analisis Faktor-Faktor yang Berpengaruh Terhadap Kecenderungan Kecurangan Akuntansi : Studi pada Perusahaan Publik dan Badan Usaha Milik Negara (BUMN) di Indonesia”. Jurnal Riset Akuntansi Indonesia vol.9, hal 21-37 